\title{
Article \\ Quantification of the Adhesion Strength of Candida albicans to Tooth Enamel
}

\author{
Gubesh Gunaratnam ${ }^{1, *,+}{ }^{\oplus}$, Johanna Dudek ${ }^{2,+}$, Philipp Jung ${ }^{1}$, Sören L. Becker ${ }^{1}{ }^{\circledR}$, Karin Jacobs ${ }^{3,4}$, \\ Markus Bischoff $1, \ddagger$ and Matthias Hannig $2, \ddagger$ \\ 1 Institute of Medical Microbiology and Hygiene, Saarland University, 66421 Homburg, Germany; \\ philipp.jung@uks.eu (P.J.); soeren.becker@uks.eu (S.L.B.); markus.bischoff@uks.eu (M.B.) \\ 2 Clinic of Operative Dentistry and Periodontology, Saarland University, 66421 Homburg, Germany; \\ johanna.dudek@uks.eu (J.D.); matthias.hannig@uks.eu (M.H.) \\ 3 Experimental Physics, Saarland University, 66123 Saarbrücken, Germany; k.jacobs@physik.uni-saarland.de \\ 4 Max Planck School Matter to Life, 69120 Heidelberg, Germany \\ * Correspondence: gubesh.gunaratnam@uks.eu; Tel.: +49-6841-16-23962 \\ $\dagger$ These authors contributed equally. \\ $\ddagger$ These authors contributed equally.
}

Citation: Gunaratnam, G.; Dudek, J.; Jung, P.; Becker, S.L.; Jacobs, K.; Bischoff, M.; Hannig, M.

Quantification of the Adhesion Strength of Candida albicans to Tooth Enamel. Microorganisms 2021, 9, 2213. https://doi.org/10.3390/

microorganisms 9112213

Academic Editor: Clarissa J. Nobile

Received: 24 September 2021

Accepted: 21 October 2021

Published: 25 October 2021

Publisher's Note: MDPI stays neutral with regard to jurisdictional claims in published maps and institutional affiliations.

Copyright: (c) 2021 by the authors. Licensee MDPI, Basel, Switzerland. This article is an open access article distributed under the terms and conditions of the Creative Commons Attribution (CC BY) license (https:/ / creativecommons.org/licenses/by/ $4.0 /)$.

\begin{abstract}
Caries is one of the most prevalent diseases worldwide, which is caused by the degradation of the tooth enamel surface. In earlier research the opportunistic pathogen Candida albicans has been associated with the formation of caries in children. Colonization of teeth by C. albicans starts with the initial adhesion of individual yeast cells to the tooth enamel surface. In this study, we visualized the initial colonization of $C$. albicans yeast cells on pellicle-covered enamel by scanning electron microscopy. To quantitatively unravel the initial adhesion strength, we applied fluidic force microscopy-based single-cell force spectroscopy to examine the key adhesion parameters adhesion force, rupture length and de-adhesion work. We analyzed single saliva-treated or untreated yeast cells on tooth enamel specimens with or without salivary pellicle. Under all tested conditions, adhesion forces in the lower nanonewton range were determined. Furthermore, we have found that all adhesion parameters were enhanced on the pellicle-covered compared to the uncovered enamel. Our data suggest that initial adhesion occurs through a strong interaction between yeast cell wall-associated adhesins and the salivary pellicle. Future SCFS studies may show whether specific management of the salivary pellicle reduces the adhesion of $C$. albicans on teeth and thus contributes to caries prophylaxis.
\end{abstract}

Keywords: single-cell force spectroscopy; Candida albicans; dental caries; adhesion

\section{Introduction}

The opportunistic pathogen Candida albicans is a common fungal species found in the human oral cavity. It is a polymorphic organism growing as yeast cells, or as filamentous true hyphae or pseudohyphae. C. albicans builds well-structured and dynamic biofilms which are the preferred growth form to ensure microbial presence in the oral cavity [1-3]. Multi- or dual-species biofilms formed between C. albicans and bacteria, such as Actinomyces viscosus or Streptococcus mutans, are often associated with denture stomatitis, periodontitis, and dental caries, especially in children with severe early childhood caries (ECC) [4-6].

ECC is one of the most prevalent children diseases and remains a global public health concern [7]. Particularly, teeth infiltrations with C. albicans were found in a high percentage of children with caries [8], and deep carious lesions with mono or dual C. albicans and non-albicans Candida species were found in a recent work [9]. Furthermore, in the dental plaques of ECC-suffering children a 3-fold higher number of C. albicans cells was found than in the saliva of these children [10]. It has been stated that a high oral Candida spp. carriage correlates with the severity of ECC $[9,11,12]$. 
In the oral cavity, saliva-exposed tooth surfaces are covered by a salivary pellicle, a tooth bio-conditioning formed by the adsorption of macromolecules from saliva [13]. Beyond protective properties, the role of salivary pellicle as a binding platform for $C$. albicans has been thoroughly investigated [14-21]. Studies reported the adhesion of C. albicans to both, uncovered or saliva-covered tooth enamel, or to hydroxyapatite, the mineral component of the enamel [21,22]. Others demonstrated that adsorbed saliva on hydroxyapatite clearly increased the adhesion of $C$. albicans to this substratum [23,24]. However, these studies determined the number of adherent cells in adhesion assays, which last several minutes to hours. To characterize the adhesion process of $C$. albicans to tooth enamel fully, it is necessary to know the adhesion forces or the de-adhesion work of single $C$. albicans yeast cells on untreated or saliva-treated tooth enamel, ideally at a very early (initial) contact formation-time point.

Fluidic force microscopy (FluidFM)-based single-cell force spectroscopy (SCFS) is a force-sensitive technique to study the adhesion strength of individual bacterial, fungal or mammalian cells to a substratum, such as biological or medically-relevant surfaces [25-28]. The FluidFM combines an atomic force microscope (AFM) cantilever with a microfluidic channel that can be used to immobilize single cells at the free end of the cantilever $[25,27,29]$. Additionally, AFM-based SCFS allows to quantify the adhesion of microbial cells covered with bodily fluids, like saliva or blood plasma [27,28,30,31].

In this study, FluidFM-based SCFS was used to quantify the initial adhesion strength between C. albicans yeast cells and bovine tooth enamel specimens for short contact times $(0 \mathrm{~s}$ and $5 \mathrm{~s}$ ). To analyze the influence of saliva on the adhesion, saliva-treated and untreated yeast cells and enamel were used. To mimic the conditions of the adhesion within the oral cavity more closely, we additionally studied the initial adhesion of the yeast cells to an in situ-formed 3 min-pellicle. Furthermore, the colonization of $C$. albicans on tooth enamel surfaces was visualized by scanning electron microscopy (SEM). Under all tested conditions, we found a strong adhesion of $C$. albicans yeast cells to tooth enamel specimens with adhesion forces in the nanonewton and de-adhesion work in the femtojoule range. For both saliva-untreated and -treated yeast cells, the adhesion strength was significantly higher on the pellicle-covered than on the uncovered tooth enamel surface, already noticeable at the indicated short contact times.

\section{Materials and Methods}

\subsection{Yeast Strain and Cultivation}

C. albicans (Robin) Berkhout strain ATCC 10231 was obtained from the German Collection of Microorganisms and Cell Cultures (DSMZ). The yeast cultivation protocol was adapted from a work published earlier [27]. Briefly, strain ATCC 10231 was cultivated on solid trypticase soy agar (TSA) plates with $5 \%$ sheep blood and kept for a maximum of 2 weeks at $4{ }^{\circ} \mathrm{C}$. For the experiments, yeast-phase cells were grown in yeast extract peptone dextrose (YPD) liquid medium (Becton Dickinson $\mathrm{GmbH}$, Heidelberg, Germany) for $19 \mathrm{~h}$ under aerobic conditions at $150 \mathrm{RPM}$ and $37^{\circ} \mathrm{C}$, with a flask to medium ratio of 12.5 to 1 .

\subsection{Enamel Samples}

Enamel samples $(3 \times 4 \times 1 \mathrm{~mm})$ were prepared from the vestibular surfaces of bovine incisor teeth. The surfaces were progressively polished by wet grinding with up to 4000 grit (Buehler, Düsseldorf, Germany) and purified from impurities by incubation in 3\% $\mathrm{NaOCl}$ for $3 \mathrm{~min}$, ultrasonication with distilled water for $10 \mathrm{~min}$, incubation in 70\% isopropyl alcohol for $15 \mathrm{~min}$ and final incubation in distilled water for at least $12 \mathrm{~h}$. For SCFS measurement, the enamel sample was fixed on a FluoroDish Cell Culture Dish (World Precision Instruments GmbH, Friedberg, Germany) with instant glue (Pattex, Düsseldorf, Germany) and immediately covered with $20 \mu \mathrm{L}$ PBS. 


\subsection{Human Subjects}

Orally examined healthy subjects gave their informed consent to participate in this study. The study was conducted in accordance with the Declaration of Helsinki. Saliva and pellicle collection protocols were approved by the medical ethics committee of the Medical Association of Saarland, Germany (proposal \# 238/03, 2016, and 54/21, 2021).

\subsection{Saliva Treatment of Yeast and Enamel}

Human saliva was collected from 12 subjects, centrifuged twice for $10 \mathrm{~min}$ at $14,000 \mathrm{rpm}$ and $2{ }^{\circ} \mathrm{C}$ to remove the oral microflora, such as yeasts and bacteria, pooled, and stored at $-80{ }^{\circ} \mathrm{C}$ until use.

For the treatment with saliva, yeast cells of the 19-h liquid culture were centrifuged at $5000 \mathrm{rpm}$ for $5 \mathrm{~min}$ and washed twice in $1 \mathrm{~mL}$ PBS. Subsequently, $1 \mathrm{~mL}$ of a cell suspension with an $\mathrm{OD}_{600}$ of 3 was centrifuged, the yeast pellet was resuspended in $100 \mu \mathrm{L}$ saliva and incubated for $15 \mathrm{~min}$ at $37^{\circ} \mathrm{C}$. After incubation, the cell-saliva mixture was filled up to $1.5 \mathrm{~mL}$ with PBS and centrifuged. The washing step was repeated once with $1 \mathrm{~mL}$ PBS. The pellet was then resuspended in $1 \mathrm{~mL}$ PBS.

For in vitro pellicle formation on tooth enamel, the polished enamel sample was fixed on a FluoroDish Cell Culture Dish, covered with $20 \mu \mathrm{L}$ saliva for 3 min at $37^{\circ} \mathrm{C}$, washed 4 times with PBS, and covered with $20 \mu \mathrm{L}$ PBS prior to SCFS.

\subsection{Oral Exposure}

In situ pellicle formation was performed as previously described [32]. After $3 \mathrm{~min}$ of oral exposure, enamel samples were removed from the oral cavity, washed with distilled water, dried with a tissue on the bottom side of the tooth enamel, fixed on FluoroDish Cell Culture Dishes and covered with $20 \mu \mathrm{L}$ PBS.

\subsection{Single-Cell Force Spectroscopy}

For SCFS, $1 \mu \mathrm{L}$ of a diluted ( $\sim \mathrm{OD}_{600}$ of 0.3 ) yeast cell liquid culture (see above) was directly pipetted on the surface of the FluoroDish into $2 \mu \mathrm{L}$ PBS in a distance of $\sim 0.5 \mathrm{~cm}$ away from the tooth enamel sample. Shortly after their deposition, yeast cells were covered together with the tooth enamel in a single drop of PBS. Yeast cells were allowed to sediment for $15 \mathrm{~min}$ in the closed dish without drying.

SCFS experiments were performed on a Flex-Bio atomic force microscope (Nanosurf $\mathrm{GmbH}$, Liestal, Switzerland) with a FluidFM ${ }^{\circledR}$ module mounted on top of a Zeiss Observer Z1 microscope (Carl Zeiss, Jena, Germany). Tipless FluidFM micropipettes (Cytosurge AG, Glattbrug, Switzerland) with a nominal spring constant of $0.3 \mathrm{~N} / \mathrm{m}$ and an aperture of $2 \mu \mathrm{m}$ were used. Ovoid yeast cells were brought into optical focus (500-fold magnification). Cells with a roughly $4 \mu \mathrm{m} \times 5 \mu \mathrm{m}$ size were selected for SCFS measurements. For functionalization, a single yeast cell was approached with a cantilever setpoint of $10 \mathrm{nN}$ and a pressure of -400 mbar for a few hundreds of milliseconds. A pressure of $-350 \mathrm{mbar}$ was adjusted to hold the cell during measurements. To characterize the adhesion properties, force-distance curves on the enamel were conducted with a ramp size of $5 \mu \mathrm{m}$, approach and retraction speed of $800 \mathrm{~nm} / \mathrm{s}$, and a force setpoint of $10 \mathrm{nN}$. Surface contact time delays of $0 \mathrm{~s}$ and $5 \mathrm{~s}$ have been tested. Five force-distance curves were recorded for each cell, with a lateral distance of at least $10 \mu \mathrm{m}$ between reading points to ensure the same spot was not probed twice. The retraction part of the force-distance curves was quantified for adhesion force, rupture length and de-adhesion work with SPIP software version 6.6.2 (Image Metrology, Hørsholm, Denmark) and OriginPro 2019b (OriginLab, Northampton, MA, USA).

\subsection{Scanning Electron Microscopy (SEM)}

Saliva-treated C. albicans yeast cells (see above) were incubated for $15 \mathrm{~min}$ on enamel surfaces covered with an in situ-generated $3 \mathrm{~min}$-pellicle (see above), and subsequently fixed overnight at $4{ }^{\circ} \mathrm{C}$ with fixing solution ( $4 \%$ glutaraldehyde; $0.1 \mathrm{M}$ cacodylate $/ \mathrm{HCl}$ 
$\mathrm{pH}$ 6.8). After washing 5 times with a cacodylate buffer (0.1 M cacodylate/ $\mathrm{HCl} \mathrm{pH} 7.5)$ for $10 \mathrm{~min}$ and contrasting with $2 \%$ osmium tetroxide in the cacodylate buffer for $2 \mathrm{~h}$, the samples were washed 5 times with distilled water, dehydrated in ethanol solutions with increasing concentrations $(50 \%, 70 \%, 90 \%, 100 \%)$ and dried overnight. Before sputtering with carbon (Bal-tec SCD 030 sputter coater, Leica Microsystems, Vienna, Austria) and gold (Bal-tec SCD 005 sputter coater, Leica Microsystems, Vienna, Austria) the specimens were fractured in 2 pieces to enable viewing from the site. Imaging was performed using a Philips/FEI XL30 ESEM FEG microscope (FEI, Eindhoven, The Netherlands).

\subsection{Statistical Analyses}

The statistical significance of changes of all data distributions between 2 groups was assessed by Mann-Whitney $U$ test and between 3 groups by Kruskal-Wallis test followed by post-hoc analysis implemented in the OriginPro2019b software (OriginLab, Northampton, MA, USA). Identified $p$-values $<0.05$ were considered statistically significant.

\section{Results}

To visualize the initial adhesion of $C$. albicans yeast cells to tooth enamel, SEM was applied. The resulting micrographs showed saliva-treated yeast cells adhering to in-situ pellicle-covered enamel (Figure 1).

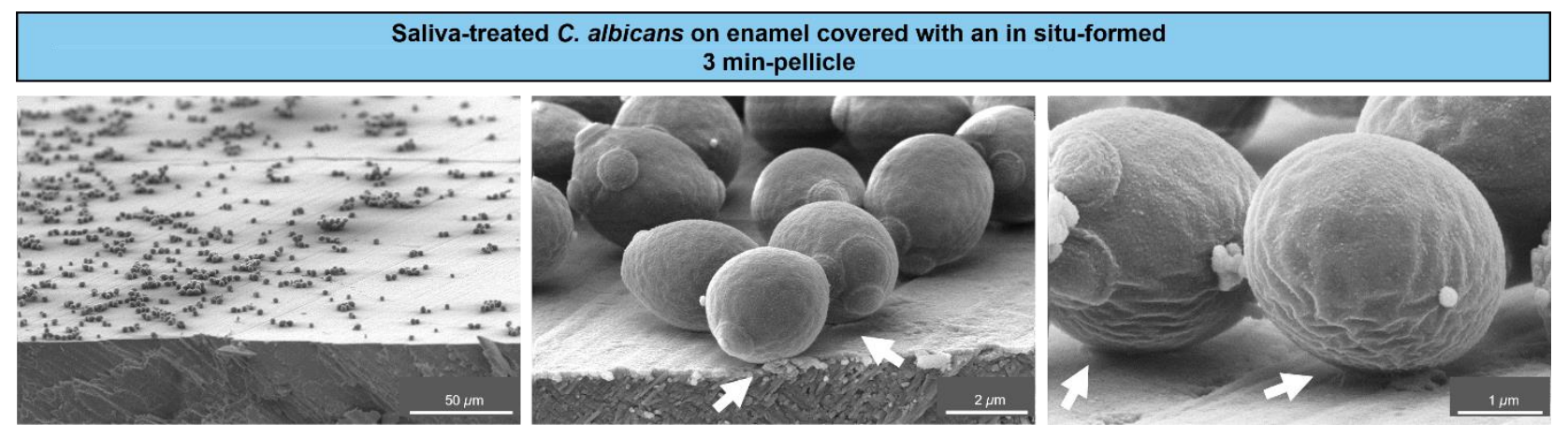

Figure 1. Scanning electron microscopy of C. albicans colonizing tooth enamel. Representative micrographs of $C$. albicans yeast cells from a liquid growth culture and after saliva treatment, which were left to adhere on tooth enamel covered with an in situ-formed 3 min-pellicle. Arrows indicate the contact sites between the cells and the salivary pellicle.

A distinct coverage of the enamel surface by $C$. albicans cells was visible at lower magnifications (left panel). Higher magnifications (middle and right panels) revealed close contact sites between the cells and the salivary pellicle, as indicated by the arrows. This illustrated an early settlement of individual C. albicans cells on tooth enamel at close to physiological intraoral conditions.

The initial single-cell adhesion properties (i.e., adhesion force $\left[\mathrm{F}_{\mathrm{adh}}\right]$, rupture length [ $\left.\mathrm{L}_{\text {rupt }}\right]$, and de-adhesion work $\left.\left[\mathrm{W}_{\mathrm{adh}}\right]\right)$ of single $C$. albicans yeast cells on bovine tooth enamel were next quantified by SCFS (Figure 2a). An overview of the tested, different measurement conditions is shown in Figure $2 b$.

Firstly, the adhesion force $\mathrm{F}_{\mathrm{adh}}$ of single $\mathrm{C}$. albicans yeast cells on bovine tooth enamel was determined with or without the presence of human saliva. When we looked at the mean adhesion forces for a short contact time $(\mathrm{t}=0 \mathrm{~s}), \mathrm{F}_{\mathrm{adh}}$ of $3.3 \pm 2.1 \mathrm{nN}$ and $8.4 \pm 6.2 \mathrm{nN}$ were determined on untreated and human saliva-treated tooth enamel, respectively. To test $\mathrm{F}_{\mathrm{adh}}$ for a higher contact time, we increased the surface contact time delay to $t=5 \mathrm{~s}$, which resulted in an elevated $F_{\text {adh }}$ of $12.4 \pm 3.6 \mathrm{nN}$ and $20.0 \pm 6.0 \mathrm{nN}$ for the respective tooth enamel conditions (Figure 3a). 


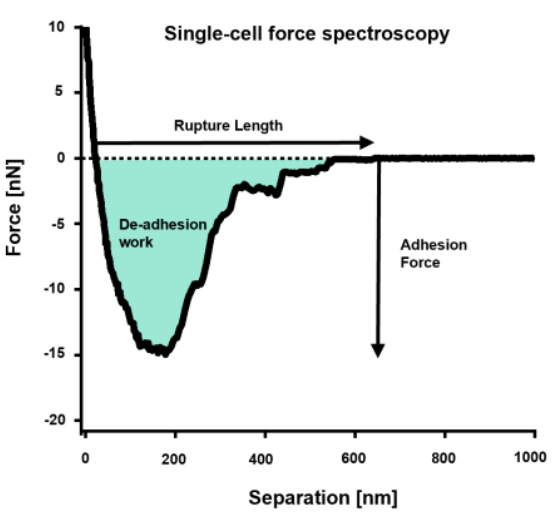

(a)
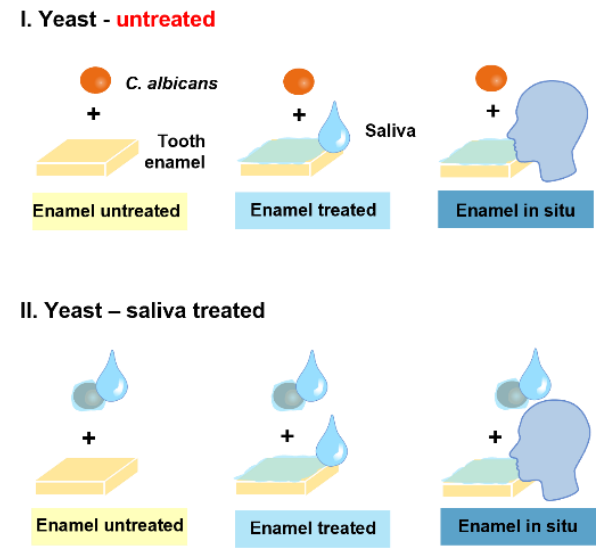

(b)

Figure 2. Single-cell force spectroscopy with C. albicans and experimental conditions. (a): FluidFM was used to bring a single cell into contact with a bovine tooth enamel sample for short surface contact times of $0 \mathrm{~s}$ or $5 \mathrm{~s}$. The yeast probe was then retracted, and the adhesion force, rupture lengths and de-adhesion work were quantified (b): The experimental design.

These results indicate that salivary macromolecules bound to the tooth enamel surface facilitate the adhesion of the yeast towards the surface of the tooth. Furthermore, expanding the surface contact time delay from $0 \mathrm{~s}$ to $5 \mathrm{~s}$ increases $\mathrm{F}_{\mathrm{adh}}$ in general. At a closer look on the individual cell adhesion forces, we frequently observed high $\mathrm{F}_{\mathrm{adh}}$ on saliva-treated enamel and lower $\mathrm{F}_{\mathrm{adh}}$ on untreated tooth enamel (Figure 3b). Analyzing $\mathrm{L}_{\mathrm{rupt}}$ as well, which marks the distance where the last bonds between $C$. albicans and the tooth enamel are disrupted, this parameter was significantly higher on saliva-treated tooth enamel $(720.9 \pm 167.3 \mathrm{~nm})$ than on untreated tooth enamel (558.8 $\pm 111.2 \mathrm{~nm}$; Figure 3c). This strongly indicates an interaction between $C$. albicans cell-surface components and saliva biomolecules on the enamel surface. Investigation of the de-adhesion work $W_{\text {adh }}$, which comprises all binding and rupture events included in the detachment process of the yeast cell from the surface, yielded in a mean $W_{\text {adh }}$ significantly increased by a factor of 2.2 on saliva-treated enamel when compared to untreated enamel for a surface contact time delay of $5 \mathrm{~s}$ (Figure 3d). Furthermore, $W_{\text {adh }}$ of $C$. albicans yeast cells on an in situ-generated 3 min pellicle on tooth enamel was also determined. Here, we found $W_{\text {adh }}$ values similar to those recorded on saliva-treated enamel, which were by a factor of 2.5 higher than on untreated tooth enamel (Figure 3d).

Given that circulating C. albicans yeast cells are exposed to saliva in the oral cavity, we next investigated whether and how the decoration of the yeast cell surface with salivary factors affected the adhesion of $C$. albicans to tooth enamel. Our measurements revealed for $\mathrm{t}=0 \mathrm{~s} \mathrm{~F}_{\mathrm{adh}}$ values of $1.6 \pm 0.5 \mathrm{nN}$ and $6.0 \pm 2.0 \mathrm{nN}$ for saliva-treated yeast cells on untreated and saliva-treated tooth enamel, respectively (Figure 4a). Increasing the surface contact time delay to $5 \mathrm{~s}$ resulted in an increase of the $\mathrm{F}_{\mathrm{adh}}$ to $6.5 \pm 1.5 \mathrm{nN}$ on untreated enamel and to $17.7 \pm 6.8 \mathrm{nN}$ on saliva-treated enamel. Here, all individual cells brought into contact with the saliva-treated enamel bound with strong $\mathrm{F}_{\text {adh }}$, while on untreated tooth enamel $\mathrm{F}_{\text {adh }}$ was comparably low in all cases (Figure $4 \mathrm{~b}$ ). Values for $\mathrm{L}_{\text {rupt }}$ reached $703.2 \pm 215.9 \mathrm{~nm}$ on saliva-treated tooth enamel and were significantly higher than on untreated tooth enamel $(479.4 \pm 105.1 \mathrm{~nm})$, indicating an extended binding of macromolecules of the saliva-treated yeast cell surface to salivary macromolecules deposited on the enamel (Figure 4c). $W_{\text {adh }}$ of the saliva-treated yeast cells was also strongly increased on saliva-treated tooth enamel (Figure 4d), and more than 4-fold higher when compared to the untreated equivalent. In order to further approach the putative adhesion scenario encountered between $C$. albicans and the enamel in the oral cavity, we also determined $W_{\text {adh }}$ produced by saliva-treated yeast cells on in situ-generated pellicles (Figure $4 \mathrm{~d}$ ). The $\mathrm{W}_{\text {adh }}$ values observed here were in a similar range to those observed for saliva-treated 
enamel and confirmed the strong adhesion strength of the saliva-treated yeast cells on salivary pellicles (Figure $4 \mathrm{~d}$ ).

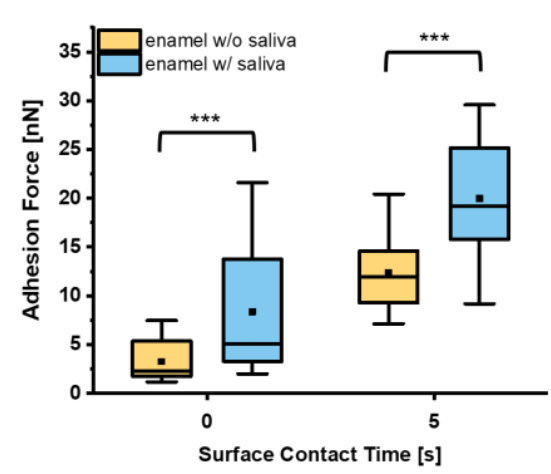

(a)

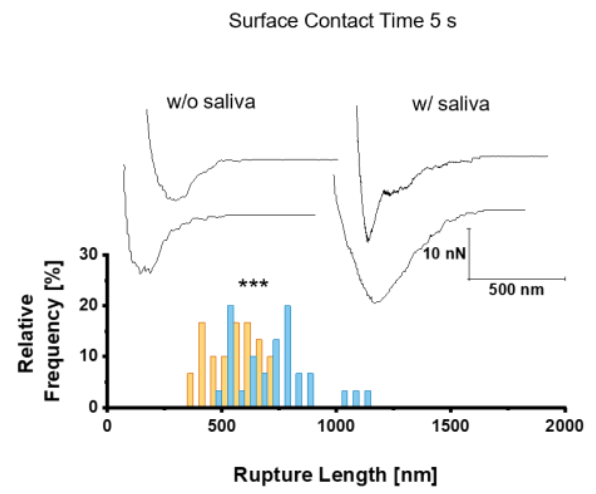

(c)

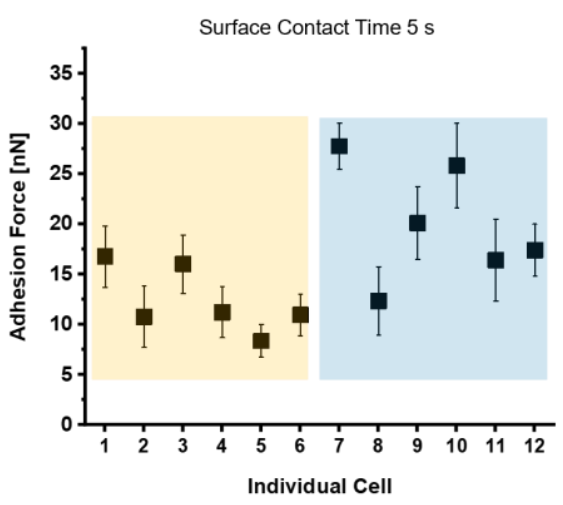

(b)

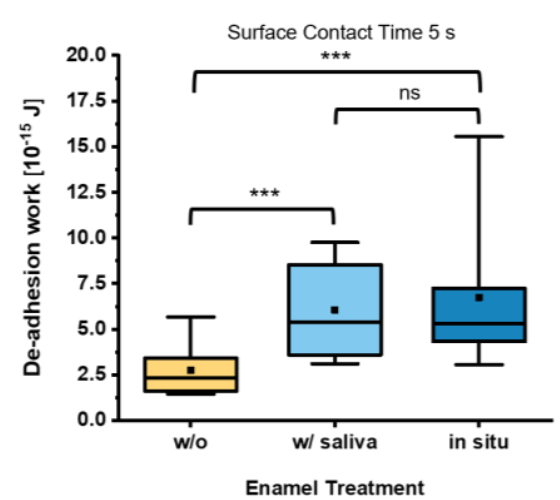

(d)

Figure 3. Adhesion of untreated Candida albicans yeast cells to tooth enamel and the impact of salivary pellicle. (a) Adhesion forces of $C$. albicans yeast cells to untreated or saliva-treated enamel and for surface contact time delays of $0 \mathrm{~s}$ and $5 \mathrm{~s}$. Data are presented in box and whisker plots (min-to-max), with median (horizontal line) and mean value (closed square). For each box 30 data points of six individual cells with five data points per cell are depicted. ${ }^{* * *}, p<0.001$ (Mann-Whitney U Test). (b) Adhesion forces of individual yeast cells. Shaded areas indicate treatment of the enamel $\mathrm{w} / \mathrm{o}$ (orange) or w/(blue) saliva. Mean adhesion forces and standard deviations are indicated. (c) Representative retraction curves for untreated (left) and saliva-treated (right) enamel and rupture lengths for a surface contact time delay of $5 \mathrm{~s}$. The histogram for rupture lengths consists of a bin size equivalent to $50 \mathrm{~nm}$. ${ }^{* * *}, p<0.001$ (Mann-Whitney U Test). (d) De-adhesion work of yeast cells for a contact time of $5 \mathrm{~s}$ for untreated, saliva-treated, and in situ-exposed tooth enamel. Data are presented in box and whisker plots (min-to-max), with median (horizontal line) and average (closed square). For each box 30 data points of six individual cells with five data points per cell are depicted. ns, not significant; ${ }^{* * *}, p<0.001$ (Kruskal-Wallis test followed by post-hoc analysis).

Our SCFS experiments demonstrated that both naïve and saliva-treated C. albicans yeast cells bound strongly to tooth enamel that was covered with a salivary pellicle. Thus, we wondered whether the underlying adhesion mechanism might be the same. To examine this, we produced an overlay of retraction curves generated with naïve and saliva-treated C. albicans yeast cells on in situ-formed pellicles to examine the adhesion mechanism under preferably physiological conditions (Figure 5). Here, we observed $\mathrm{F}_{\text {adh }}$ values of $21.12 \pm 10.0 \mathrm{nN}$ for untreated yeast cells and $15.72 \pm 8.6 \mathrm{nN}$ for saliva-treated yeast cells (Figure $5 \mathrm{a}, \mathrm{b}$ insets). Interestingly, for untreated yeast cells, the $\mathrm{F}_{\mathrm{adh}}$ maxima were observed at a separation distance of $197.4 \pm 45.8 \mathrm{~nm}$, while for saliva-treated yeast cells the separation distances were shifted to $298.0 \pm 59.3 \mathrm{~nm}$. These findings demonstrate that 
the salivary treatment of the $C$. albicans yeast-cell surface moves the separation of $\mathrm{F}_{\text {adh }}$ by approximately $100 \mathrm{~nm}$. Possible explanations for this observation might be that the binding of some cell-wall components at shorter distances was inhibited, and/or that the binding mechanism for some of the yeast adhesins was altered or masked in the presence of soluble salivary biomolecules.

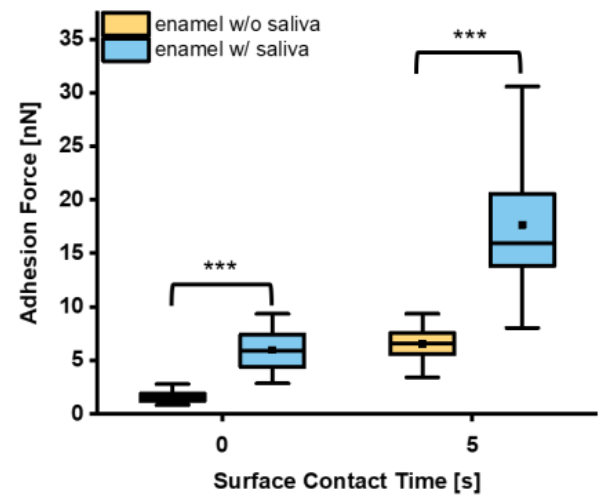

(a)

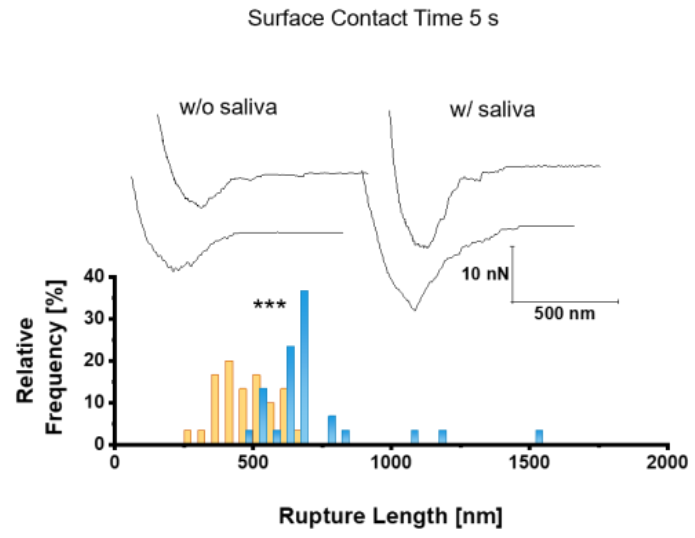

(c)

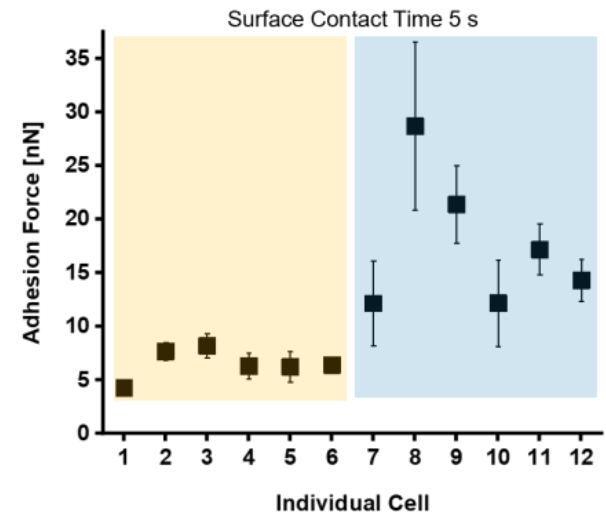

(b)

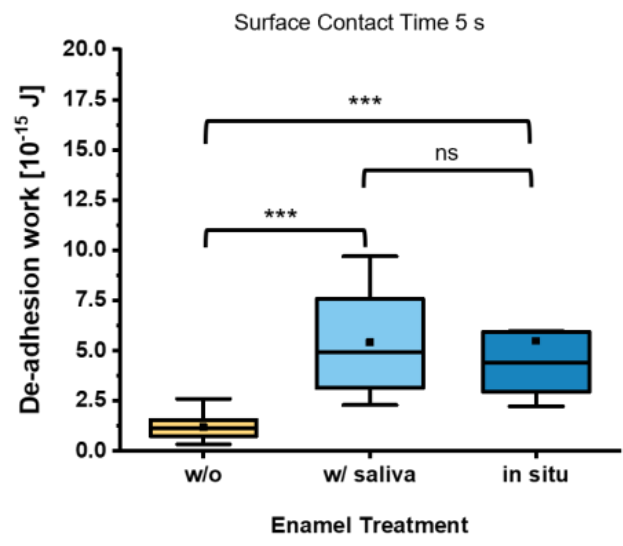

(d)

Figure 4. Adhesion of saliva-treated Candida albicans yeast cells to tooth enamel. (a) Adhesion forces of saliva-treated C. albicans yeast cells to untreated or saliva-treated enamel and for surface contact time delays of $0 \mathrm{~s}$ and $5 \mathrm{~s}$. Data are presented in box and whisker plots (min-to-max), with median (horizontal line) and mean value (closed square). For each box 30 data points of six individual cells with five data points per cells are depicted. ${ }^{* *}, p<0.001$ (Mann-Whitney U Test). (b) Adhesion forces of individual yeast cells. Shaded areas indicate treatment of the enamel w/o (orange) or w/(blue) saliva. Mean adhesion forces and standard deviations are indicated. (c) Representative retraction curves for untreated (left) and saliva-treated (right) enamel and rupture lengths for a surface contact time delay of $5 \mathrm{~s}$ are shown. The histogram for rupture lengths consists of a bin size equivalent to $50 \mathrm{~nm}$. ${ }^{* * *}, p<0.001$ (Mann-Whitney U Test). (d) De-adhesion work of yeast cells for a surface contact time delay of $5 \mathrm{~s}$ for the untreated, saliva-treated, and in situ-exposed tooth enamel. Data from five to six individual cells with five data points per cell are presented in box and whisker plots (min-to-max), with median (horizontal line) and average (closed square). ns, not significant; ***, $p<0.001$ (Kruskal-Wallis test followed by post-hoc analysis). 


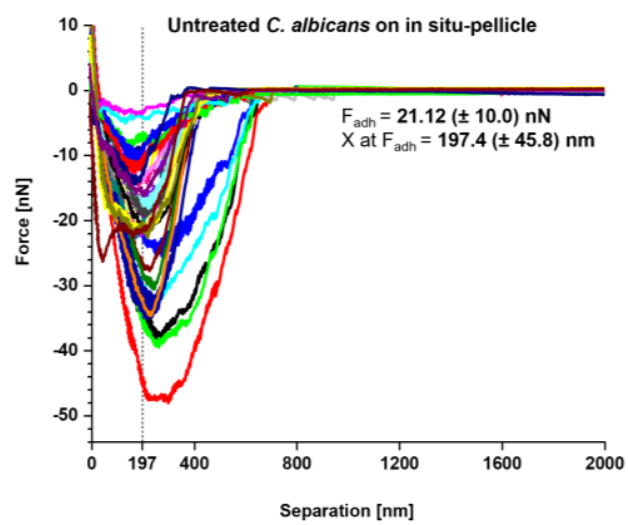

(a)

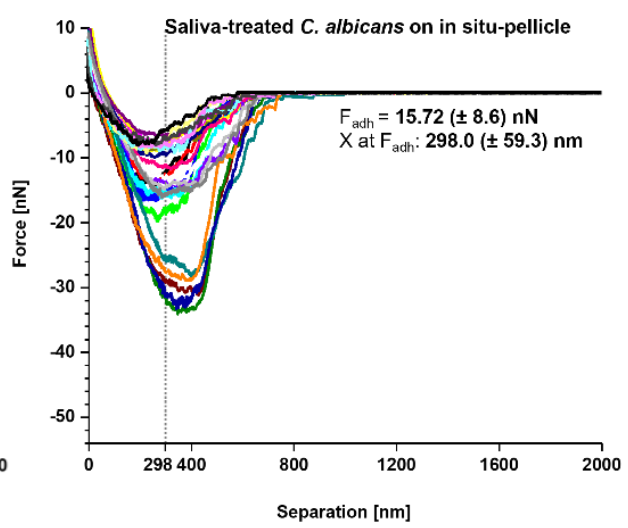

(b)

Figure 5. Comparison of adhesion forces between untreated and saliva-treated Candida albicans yeast cells on in situ pellicles of tooth enamel. Overlay of retraction curves on in situ-formed pellicles on tooth enamel. (a) Data for untreated C. albicans yeast cells $(n=35)$ and $(\mathbf{b})$ for saliva-treated C. albicans yeast cells $(n=25)$. In each panel the mean adhesion force $\left(\mathrm{F}_{\mathrm{adh}}\right)$ and the mean separation length of the adhesion force $\left(\mathrm{X}\right.$ at $\left.\mathrm{F}_{\mathrm{adh}}\right)$ are given.

\section{Discussion}

In this work, the initial binding of $C$. albicans to in-situ pellicles on enamel was visualized by scanning electron microscopy, showing adherent yeast cells on the tooth enamel surface with close contact sites to the salivary pellicle. Earlier observations of a 10-days mature C. albicans biofilm on cleaned tooth enamel demonstrated a complex conglomerate of yeast cells and hyphae, and mycelium formation [33]. Thus, the initial binding of single $C$. albicans yeast cells can lead to the colonization of the tooth surface, and might serve as a bridging factor for other microorganisms to build up polymicrobial, cariogenic biofilms [9,33-35].

Our FluidFM-based SCFS studies demonstrated adhesion forces for C. albicans yeast cells on tooth enamel in the lower nanonewton range, which is in the same dimension as for this yeast morphotype on artificial surfaces, such as hydrophobic and hydrophilic dodecyl phosphate surfaces, nanostructured gold surfaces, or polyurethane-based central venous catheter $(\mathrm{CVC})$ tubing $[25,27,36]$. Additionally, similar to the findings made with C. albicansgerminated cells on human blood plasma-coated CVC tubing [27], we observed enhanced adhesion for C. albicans yeast cells on the bio-conditioned, pellicle-covered tooth enamel. One putative explanation for this observation is a pronounced tethering of yeast cellsurface adhesins to the salivary components in the pellicle. The outer cell wall of C. albicans consists among others of mannoproteins with adhesive functions [37]. Such adhesion factors were found to be crucial in Staphylococcus aureus for the adhesion on silicon wafers, due to strong tethering and stretching of proteins, and the stepwise unlocking of protein domains $[30,38]$. We assume that the same is true for $C$. albicans yeast cells displaying stretchable mannoproteins on their surface [39], such as the Als proteins, which exhibit adhesive functions and are ideal candidates for abiotic surface binding or interactions with human extracellular proteins $[40,41]$. Indeed, recent work reported that the yeast proteins Als1, endoglucanase Bgl2, and the cell wall-anchored Ecm33 contribute to the binding of yeast cells to saliva-covered hydroxyapatite, the mineral component of enamel [24]. Earlier work demonstrated already that $C$. albicans yeast cells adhere in larger quantities to saliva-treated HAP surfaces than to untreated HAP [23,24]. Potential ligands in the salivary pellicle might be basic proline-rich proteins (PRPs), such as IB-6, the calcium-binding protein statherin, and BPIFA $2[32,42,43]$. Interestingly, the adhesion forces, rupture lengths and the de-adhesion work show a larger range of values on saliva-treated enamel than on untreated enamel. We assume that this is due to an individual cell-wall composition of yeast adhesins that specifically bind salivary ligands, and because of an inhomogeneous 
deposition of salivary biomolecules on the substratum [44]. The adhesion of the yeast cell to the untreated tooth enamel is mediated through unspecific interactions with a narrow range for adhesion forces. However, the presence of pellicle-specific interactions between yeast adhesins and individual salivary ligands might lead to weaker or stronger binding forces, depending on the number of yeast adhesins coming into contact with the pellicle and on the type and number of ligands available in the pellicle [37,42]. Such a scenario is also in line with the increase in rupture lengths, when loosely adsorbed salivary macromolecules that come into contact with the yeast cell surface will be stretched in the adhesion process.

It is worth noticing that the supportive effect of pellicle for the initial adhesion of C. albicans to tooth enamel might be seen only with early pellicles (i.e., 3 min-pellicle), as previous work observed a reduced adhesion capacity of $C$. albicans to dental acrylic surfaces decorated with matured salivary pellicles (i.e., $18 \mathrm{~h}$-pellicle) compared to the PBS control [16]. However, direct comparison between SCFS and traditional, cell number determining-adhesion assays should be made with caution. SCFS is a force-sensitive method and directly quantifies the initial adhesion of a cell after contact to a substratum. Future SCFS studies should thus investigate the adhesion of $C$. albicans to matured pellicles, and include $C$. albicans deletion mutants that do not synthesize single or multiple adhesion factors. This will help to further elucidate the molecular mechanisms behind the adhesion of $C$. albicans to pellicle-covered enamel.

Given that $C$. albicans cells circulating in the oral cavity are constantly exposed to saliva, we also investigated whether and how the covering of the yeast cell surface with saliva affects the cell's ability to adhere to the enamel. Again, we observed a stronger C. albicans adhesion strength on pellicle-covered than on untreated enamel. This suggests that the binding of C. albicans and its macromolecular adhesins to available salivary ligands in the pellicles is largely preserved. One explanation for this might be the maintenance of the binding activity of the fungal adhesins through their capacity to differentiate between salivary biomolecules in solution and in the pellicle. It has been suggested that $C$. albicans does not bind some salivary ligands (e.g., PRPs), when these are in solution, which has been shown for the oral bacterium Streptococcus gordonii [42,45]. It cannot be excluded, however, that the newly yeast cell surface-attached salivary components might mediate the adhesion to the pellicle as well, as has been suggested for saliva-coated S. aureus bacterial cells on saliva-treated titanium [31].

In our SCFS studies, we noticed a prolonged mean separation distance for the adhesion force maxima for saliva-treated yeast cells probed on in situ pellicles when compared to untreated yeast cells probed on the same kind of surface. The most likely explanation for this observation is that salivary biomolecules, which were adsorbed on the yeast cell surface, interfere with the binding of the $C$. albicans adhesins to the pellicle components. This scenario is similar to findings made with $C$. albicans and fibronectin, in which a reduced binding of $C$. albicans to immobilized fibronectin was observed when the yeast cells were pre-exposed to fibronectin in solution [46]. The observed shift of the adhesion force by a separation of almost $100 \mathrm{~nm}$ indicates that small-sized adhesins, which probably contribute substantially to the strong adhesion force observed for untreated yeast cells, are hindered from binding in saliva-treated yeast cells to the same type of surface by the interference of salivary components. In contrast, the remaining free yeast adhesins are not prevented from tethering and contribute to the observed larger separation distances for the adhesion force.

Although our SCFS studies do not provide any physicochemical information on the nature behind the adhesion strength of $C$. albicans to tooth enamel with or without pellicle, our force-distance curves indicate a simultaneous stretching of adhesive bonds, predominantly occurring between C. albicans and dental pellicles. It is likely that the nano roughness of the surface plays a key role here during these adhesion events. We have previously shown that an in situ-formed 10 min-pellicle yielded in globular agglomerates in $\mathrm{nm}$ dimension on the enamel [47]. From this, it is tempting to speculate that a synergistic effect between surface nano-roughness and specific interactions of the involved binding macromolecules contributes to the stretching of the adhesive bonds. Support for this 
hypothesis is given by a recent study showing that a coating of glass with gold particles with a density of 61 nanoparticles per $\mu \mathrm{m}^{2}$ was sufficient to significantly enhance the adhesion forces of $C$. albicans to the gold particles-treated surface when compared to the naïve glass surface [36]. Notably, the retraction curves for C. albicans yeast cells brought into contact with the gold-covered glass surface were reminiscent to our retraction curves observed with C. albicans on pellicle-covered enamel and suggest that an increase in surface nano-roughness might be already sufficient to increase the adhesion force, while specific receptor-ligand interactions may further intensify this interaction [40]. Moreover, theoretical models can be refined with our results, revealing binding processes, types of intermolecular forces and the spatial distribution of adhesion sites [48,49].

\section{Conclusions}

Our SCFS studies demonstrate that $C$. albicans yeast cells adhere strongly with $\mathrm{nN}$ adhesion forces and fJ de-adhesion work to tooth enamel, which suggests that this opportunistic pathogen possesses a repertoire of virulence factors to colonize the tooth surface. Especially on salivary pellicle, which is formed on the enamel within seconds after tooth brushing, C. albicans utilizes adsorbed ligands to bind to the tooth, which probably supports the microbe to withstand salivary flow and being swallowed by the host. Future experimental and theoretical studies will show whether the specific management of salivary pellicles leads to a reduced adhesion of $C$. albicans and can thus contribute to caries prophylaxis.

Author Contributions: Conceptualization, G.G., J.D., K.J., M.B. and M.H.; methodology, G.G., J.D. and P.J.; formal analysis, G.G., J.D. and S.L.B.; investigation, G.G. and J.D.; resources, M.B. and M.H.; writing-original draft preparation, G.G. and J.D.; writing—review and editing, P.J., S.L.B., K.J., M.B. and M.H.; visualization, G.G. and J.D.; supervision, M.B. and M.H.; project administration, M.B. and M.H.; funding acquisition, K.J., M.B. and M.H. All authors have read and agreed to the published version of the manuscript.

Funding: This research was funded by the German Research Foundation (DFG), grant numbers SFB1027/B2 and/B3.

Institutional Review Board Statement: The study was conducted according to the guidelines of the Declaration of Helsinki and approved by the medical ethics committee of the Medical Association of Saarland, Germany (proposal \# 238/03, 2016, and 54/21, 2021).

Informed Consent Statement: Informed consent was obtained from all subjects involved in the study.

Data Availability Statement: The datasets generated and analyzed during the current study are available from the corresponding author on reasonable request.

Acknowledgments: We thank Karin Hilgert, Janis Ortgies, Norbert Pütz and Jessica SchmittBennewart for excellent experimental assistance and technical support.

Conflicts of Interest: The authors declare no conflict of interest.

\section{References}

1. Bar-Or, Y. The Effect of Adhesion on Survival and Growth of Microorganisms. Experientia 1990, 46, 823-826. [CrossRef]

2. ten Cate, J.M.; Klis, F.M.; Pereira-Cenci, T.; Crielaard, W.; de Groot, P.W.J. Molecular and Cellular Mechanisms That Lead to Candida Biofilm Formation. J. Dent. Res. 2009, 88, 105-115. [CrossRef] [PubMed]

3. de Barros, P.P.; Rossoni, R.D.; de Souza, C.M.; Scorzoni, L.; Fenley, J.D.C.; Junqueira, J.C. Candida Biofilms: An Update on Developmental Mechanisms and Therapeutic Challenges. Mycopathologia 2020, 185, 415-424. [CrossRef]

4. Gulati, M.; Nobile, C.J. Candida albicans Biofilms: Development, Regulation, and Molecular Mechanisms. Microbes Infect. 2016, 18, 310-321. [CrossRef]

5. Jean, J.; Goldberg, S.; Khare, R.; Bailey, L.C.; Forrest, C.B.; Hajishengallis, E.; Koo, H. Retrospective Analysis of Candida-Related Conditions in Infancy and Early Childhood Caries. Pediatr. Dent. 2018, 40, 131-135.

6. Xiao, J.; Huang, X.; Alkhers, N.; Alzamil, H.; Alzoubi, S.; Wu, T.T.; Castillo, D.A.; Campbell, F.; Davis, J.; Herzog, K.; et al. Candida albicans and Early Childhood Caries: A Systematic Review and Meta-Analysis. Caries Res. 2018, 52, 102-112. [CrossRef]

7. O'Connell, L.M.; Santos, R.; Springer, G.; Burne, R.A.; Nascimento, M.M.; Richards, V.P. Site-Specific Profiling of the Dental Mycobiome Reveals Strong Taxonomic Shifts during Progression of Early-Childhood Caries. Appl. Environ. Microbiol. 2020, 86, e02825-19. [CrossRef] 
8. Schulz-Weidner, N.; Ansari, F.; Hossain, H.; Chakraborty, T.; Domann, E.; Wetzel, W.-E. Vergleichende PCR-Typisierung von Candida albicans aus der Mundhöhle und dem Magen-Darm-Trakt. Oralprophylaxe Kinderzahnheilkd 2005, 27, $139-143$.

9. Fakhruddin, K.S.; Perera Samaranayake, L.; Egusa, H.; Chi Ngo, H.; Panduwawala, C.; Venkatachalam, T.; Kumarappan, A.; Pesee, S. Candida Biome of Severe Early Childhood Caries (S-ECC) and Its Cariogenic Virulence Traits. J. Oral Microbiol. 2020, 12, 1724484. [CrossRef] [PubMed]

10. Xiao, J.; Moon, Y.; Li, L.; Rustchenko, E.; Wakabayashi, H.; Zhao, X.; Feng, C.; Gill, S.R.; McLaren, S.; Malmstrom, H.; et al. Candida albicans Carriage in Children with Severe Early Childhood Caries (S-ECC) and Maternal Relatedness. PLoS ONE 2016, 11, e0164242. [CrossRef]

11. de Carvalho, F.G.; Silva, D.S.; Hebling, J.; Spolidorio, L.C.; Spolidorio, D.M.P. Presence of Mutans Streptococci and Candida Spp. in Dental Plaque/Dentine of Carious Teeth and Early Childhood Caries. Arch. Oral Biol. 2006, 51, 1024-1028. [CrossRef]

12. Lozano Moraga, C.P.; Rodríguez Martínez, G.A.; Lefimil Puente, C.A.; Morales Bozo, I.C.; Urzúa Orellana, B.R. Prevalence of Candida albicans and Carriage of Candida non-albicans in the Saliva of Preschool Children, According to Their Caries Status. Acta Odontol. Scand. 2017, 75, 30-35. [CrossRef]

13. Trautmann, S.; Künzel, N.; Fecher-Trost, C.; Barghash, A.; Schalkowsky, P.; Dudek, J.; Delius, J.; Helms, V.; Hannig, M. Deep Proteomic Insights into the Individual Short-Term Pellicle Formation on Enamel-An In Situ Pilot Study. Prot. Clin. Appl. 2020, 14, 1900090. [CrossRef] [PubMed]

14. Samaranayake, L.P.; MacFarlane, T.W. Factors Affecting the In-Vitro Adherence of the Fungal Oral Pathogen Candida albicans to Epithelial Cells of Human Origin. Arch. Oral Biol. 1982, 27, 869-873. [CrossRef]

15. Lendenmann, U.; Grogan, J.; Oppenheim, F.G. Saliva and Dental Pellicle-A Review. Adv. Dent. Res. 2000, 14, 22-28. [CrossRef]

16. Samaranayake, L.P.; McCourtie, J.; MacFarlane, T.W. Factors Affecting the In-Vitro Adherence of Candida albicans to Acrylic Surfaces. Arch. Oral Biol. 1980, 25, 611-615. [CrossRef]

17. Bürgers, R.; Hahnel, S.; Reichert, T.E.; Rosentritt, M.; Behr, M.; Gerlach, T.; Handel, G.; Gosau, M. Adhesion of Candida albicans to Various Dental Implant Surfaces and the Influence of Salivary Pellicle Proteins. Acta Biomater. 2010, 6, 2307-2313. [CrossRef] [PubMed]

18. Oncul, B.; Karakis, D.; Dogruman Al, F. The Effect of Two Artificial Salivas on the Adhesion of Candida albicans to Heat-Polymerized Acrylic Resin. J. Adv. Prosthodont. 2015, 7, 93. [CrossRef]

19. O'Sullivan, J.M.; Jenkinson, H.F.; Cannon, R.D. Adhesion of Candida albicans to Oral Streptococci Is Promoted by Selective Adsorption of Salivary Proteins to the Streptococcal Cell Surface. Microbiology 2000, 146, 41-48. [CrossRef]

20. Ponton, J.; Elguezabal, N.; Maza, J.L.; Dorronsoro, S. Whole Saliva Has a Dual Role on the Adherence of Candida albicans to Polymethylmetacrylate. TODENTJ 2008, 2, 1-4. [CrossRef]

21. Nikawa, H.; Hamada, T.; Yamashiro, H.; Murata, H.; Subiwahjudi, A. The Effect of Saliva or Serum on Streptococcus Mutans and Candida albicans Colonization of Hydroxylapatite Beads. J. Dent. 1998, 26, 31-37. [CrossRef]

22. Hahnel, S.; Ettl, T.; Gosau, M.; Rosentritt, M.; Handel, G.; Bürgers, R. Influence of Saliva Substitute Films on the Initial Adhesion of Candida albicans to Dental Substrata Prior to and after Artificial Ageing. Arch. Oral Biol. 2010, 55, 391-396. [CrossRef] [PubMed]

23. Cannon, R.D.; Nand, A.K.; Jenkinson, H.F. Adherence of Candida albicans to Human Salivary Components Adsorbed to Hydroxylapatite. Microbiology 1995, 141 Pt 1, 213-219. [CrossRef]

24. Thanh Nguyen, H.; Zhang, R.; Inokawa, N.; Oura, T.; Chen, X.; Iwatani, S.; Niimi, K.; Niimi, M.; Holmes, A.R.; Cannon, R.D.; et al. Candida albicans Bgl2p, Ecm33p, and Als1p Proteins Are Involved in Adhesion to Saliva-Coated Hydroxyapatite. J. Oral Microbiol. 2021, 13, 1879497. [CrossRef]

25. Potthoff, E.; Guillaume-Gentil, O.; Ossola, D.; Polesel-Maris, J.; LeibundGut-Landmann, S.; Zambelli, T.; Vorholt, J.A. Rapid and Serial Quantification of Adhesion Forces of Yeast and Mammalian Cells. PLoS ONE 2012, 7, e52712. [CrossRef]

26. Hofherr, L.; Müller-Renno, C.; Ziegler, C. FluidFM as a Tool to Study Adhesion Forces of Bacteria-Optimization of Parameters and Comparison to Conventional Bacterial Probe Scanning Force Spectroscopy. PLoS ONE 2020, 15, e0227395. [CrossRef]

27. Jung, P.; Mischo, C.E.; Gunaratnam, G.; Spengler, C.; Becker, S.L.; Hube, B.; Jacobs, K.; Bischoff, M. Candida albicans Adhesion to Central Venous Catheters: Impact of Blood Plasma-Driven Germ Tube Formation and Pathogen-Derived Adhesins. Virulence 2020, 11, 1453-1465. [CrossRef] [PubMed]

28. Gunaratnam, G.; Spengler, C.; Trautmann, S.; Jung, P.; Mischo, J.; Wieland, B.; Metz, C.; Becker, S.L.; Hannig, M.; Jacobs, K.; et al. Human Blood Plasma Factors Affect the Adhesion Kinetics of Staphylococcus Aureus to Central Venous Catheters. Sci. Rep. 2020, 10, 20992. [CrossRef]

29. Potthoff, E.; Ossola, D.; Zambelli, T.; Vorholt, J.A. Bacterial Adhesion Force Quantification by Fluidic Force Microscopy. Nanoscale 2015, 7, 4070-4079. [CrossRef]

30. Spengler, C.; Thewes, N.; Nolle, F.; Faidt, T.; Umanskaya, N.; Hannig, M.; Bischoff, M.; Jacobs, K. Enhanced Adhesion of Streptococcus Mutans to Hydroxyapatite after Exposure to Saliva: Enhanced Adhesion of Streptococcus Mutans to Hydroxyapatite after Exposure to Saliva. J. Mol. Recognit. 2017, 30, e2615. [CrossRef]

31. Mischo, J.; Faidt, T.; McMillan, R.B.; Dudek, J.; Gunaratnam, G.; Bayenat, P.; Holtsch, A.; Spengler, C.; Müller, F.; Hähl, H.; et al. Hydroxyapatite Pellets as Versatile Model Surfaces for Systematic Studies on Enamel. bioRxiv 2021. [CrossRef]

32. Trautmann, S.; Barghash, A.; Fecher-Trost, C.; Schalkowsky, P.; Hannig, C.; Kirsch, J.; Rupf, S.; Keller, A.; Helms, V.; Hannig, M. Proteomic Analysis of the Initial Oral Pellicle in Caries-Active and Caries-Free Individuals. Prot. Clin. Appl. 2019, 13, 1800143. [CrossRef] [PubMed] 
33. Sen, B.H.; Safavi, K.E.; Spångberg, L.S. Colonization of Candida albicans on Cleaned Human Dental Hard Tissues. Arch. Oral Biol. 1997, 42, 513-520. [CrossRef]

34. Gregoire, S.; Xiao, J.; Silva, B.B.; Gonzalez, I.; Agidi, P.S.; Klein, M.I.; Ambatipudi, K.S.; Rosalen, P.L.; Bauserman, R.; Waugh, R.E.; et al. Role of Glucosyltransferase B in Interactions of Candida albicans with Streptococcus Mutans and with an Experimental Pellicle on Hydroxyapatite Surfaces. Appl. Environ. Microbiol. 2011, 77, 6357-6367. [CrossRef] [PubMed]

35. Metwalli, K.H.; Khan, S.A.; Krom, B.P.; Jabra-Rizk, M.A. Streptococcus Mutans, Candida albicans, and the Human Mouth: A Sticky Situation. PLoS Pathog. 2013, 9, e1003616. [CrossRef]

36. Dauben, T.J.; Dewald, C.; Firkowska-Boden, I.; Helbing, C.; Peisker, H.; Roth, M.; Bossert, J.; Jandt, K.D. Quantifying the Relationship between Surfaces' Nano-Contact Point Density and Adhesion Force of Candida albicans. Colloids Surf. B Biointerfaces 2020, 194, 111177. [CrossRef] [PubMed]

37. Jeng, H.-W.; Holmes, A.R.; Cannon, R.D. Characterization of Two Candida albicans Surface Mannoprotein Adhesins That Bind Immobilized Saliva Components. Med. Mycol. 2005, 43, 209-217. [CrossRef] [PubMed]

38. Thewes, N.; Thewes, A.; Loskill, P.; Peisker, H.; Bischoff, M.; Herrmann, M.; Santen, L.; Jacobs, K. Stochastic Binding of Staphylococcus Aureus to Hydrophobic Surfaces. Soft Matter 2015, 11, 8913-8919. [CrossRef]

39. Alsteens, D.; Dupres, V.; Klotz, S.A.; Gaur, N.K.; Lipke, P.N.; Dufrêne, Y.F. Unfolding Individual Als5p Adhesion Proteins on Live Cells. ACS Nano 2009, 3, 1677-1682. [CrossRef]

40. Gaur, N.K.; Smith, R.L.; Klotz, S.A. Candida Albicans and Saccharomyces Cerevisiae Expressing ALA1/ALS5 Adhere to Accessible Threonine, Serine, or Alanine Patches. Cell Commun. Adhes. 2002, 9, 45-57. [CrossRef]

41. Finkel, J.S.; Xu, W.; Huang, D.; Hill, E.M.; Desai, J.V.; Woolford, C.A.; Nett, J.E.; Taff, H.; Norice, C.T.; Andes, D.R.; et al. Portrait of Candida albicans Adherence Regulators. PLoS Pathog. 2012, 8, e1002525. [CrossRef] [PubMed]

42. O'Sullivan, J.M.; Cannon, R.D.; Sullivan, P.A.; Jenkinson, H.F. Identification of Salivary Basic Proline-Rich Proteins as Receptors for Candida albicans Adhesion. Microbiology 1997, 143, 341-348. [CrossRef] [PubMed]

43. Holmes, A.R.; Rodrigues, E.; van der Wielen, P.; Lyons, K.M.; Haigh, B.J.; Wheeler, T.T.; Dawes, P.J.D.; Cannon, R.D. Adherence of Candida albicans to Silicone Is Promoted by the Human Salivary Protein SPLUNC2/PSP/BPIFA2. Mol. Oral Microbiol. 2014, 29, 90-98. [CrossRef]

44. Hannig, C.; Helbig, R.; Hilsenbeck, J.; Werner, C.; Hannig, M. Impact of the Springtail's Cuticle Nanotopography on Bioadhesion and Biofilm Formation in Vitro and in the Oral Cavity. R. Soc. Open Sci. 2018, 5, 171742. [CrossRef] [PubMed]

45. Gibbons, R.J.; Hay, D.I.; Schlesinger, D.H. Delineation of a Segment of Adsorbed Salivary Acidic Proline-Rich Proteins Which Promotes Adhesion of Streptococcus Gordonii to Apatitic Surfaces. Infect. Immun. 1991, 59, 2948-2954. [CrossRef]

46. Klotz, S.A.; Smith, R.L. A fibronectin receptor on Candida albicans mediates adherence of the fungus to extracellular matrix. J. Infect. Dis. 1991, 163, 604-610. [CrossRef] [PubMed]

47. Hannig, M.; Herzog, S.; Willigeroth, S.F.; Zimehl, R. Atomic Force Microscopy Study of Salivary Pellicles Formed on Enamel and Glass in Vivo. Colloid Polym. Sci. 2001, 279, 479-483. [CrossRef]

48. Spengler, C.; Glatz, B.A.; Maikranz, E.; Bischoff, M.; Klatt, M.A.; Santen, L.; Fery, A.; Jacobs, K. The Adhesion Capability of S. Aureus Cells Is Heterogeneously Distributed over the Cell Envelope. bioRxiv 2021. [CrossRef]

49. Spengler, C.; Maikranz, E.; Santen, L.; Jacobs, K. Modeling Bacterial Adhesion to Unconditioned Abiotic Surfaces. Front. Mech. Eng. 2021, 7, 661370. [CrossRef] 